\title{
RESPONS DAN POLA PERTUMBUHAN BENIH IKAN BAUNG (Hemibagrus nemurus) DARI TIGA GENERASI DIPELIHARA PADA WADAH BUDIDAYA YANG BERBEDA
}

\author{
Irin Iriana Kusmini, Anang Hari Kristanto, Jojo Subagja, Vitas Atmadi Prakoso\#, dan \\ Fera Permata Putri
}

Balai Riset Perikanan Budidaya Air Tawar dan Penyuluhan Perikanan

Jl. Sempur No. 1, Bogor 16129

(Naskah diterima: 11 M ei 2018; Revisi final: 10 Juli 2018; Disetujui publikasi: 10 Juli 2018)

\begin{abstract}
ABSTRAK
Ikan baung (Hemibagrus nemurus) merupakan salah satu komoditas ikan air tawar ekonomis tinggi di Indonesia. Untuk meningkatkan produktivitas budidaya, maka dilakukan pembentukan generasi baru populasi terbaik agar diperoleh generasi yang lebih produktif dan cepat tumbuh. Tujuan penelitian ini adalah untuk mengevaluasi respons dan pola pertumbuhan benih ikan baung generasi-1 (G-1), generasi-2 (G-2), dan generasi-3 (G-3) pada wadah budidaya yang berbeda. Penelitian dilakukan di kolam semi-permanen, kolam beton dan jaring apung di Instalasi Riset Plasma Nutfah Perikanan Air Tawar, Cijeruk dengan tiga ulangan. Benih yang digunakan berukuran panjang rata-rata $1,54 \pm 0,22 \mathrm{~cm}$; dan bobot 0,06 $\pm 0,01 \mathrm{~g}$; dipelihara dengan padat tebar 50 ekor $/ \mathrm{m}^{2}$. Selama 15 hari pertama pemeliharaan benih diberi pakan Tubifex dan pakan komersial dengan kadar protein 41\%sebanyak 5\%per hari dengan frekuensi pemberian pakan dua kali sehari, untuk pemeliharaan selanjutnya pakan yang diberikan berupa pakan komersil saja. Pemeliharaan dilakukan selama 45 hari, dan pengukuran pertumbuhan dilakukan 15 hari sekali. Parameter yang diamati meliputi laju pertumbuhan spesifik, sintasan, dan pola pertumbuhan. Sebagai data pendukung dilakukan pengukuran kualitas air dan kelimpahan plankton. Hasil penelitian menunjukkan bahwa pertumbuhan bobot dan panjang benih ikan baung G-2 lebih unggul dibanding dengan G-1 dan G-3, sedangkan wadah budidaya yang terbaik adalah pada pemeliharaan di kolam semi-permanen dengan bobot ikan 6,79 \pm 4,085 g dan panjang $8,46 \pm 1,967 \mathrm{~cm}$. Pertumbuhan ikan baung yang dipelihara di kolam semi-permanen menunjukkan perbedaan yang nyata $(P<0,05)$ terhadap wadah pemeliharan lainnya. Pola pertumbuhan ikan baung dari tiga wadah budidaya bersifat allometrik negatif $(b<3)$.
\end{abstract}

\section{KATA KUNCl: ikan baung (Hemibagrus nemurus); pola pertumbuhan; sintasan; wadah budidaya}

ABSTRACT: Growth response and pattern of Asian redtail catfish (Hemibagrus nemurus) fingerlings from three generations cultured on different rearing media. By: Irin Iriana Kusmini, Anang Hari Kristanto, Jojo Subagja, Vitas Atmadi Prakoso, and Fera Permata Putri

Asian redtail catfish (Hemibagrus nemurus) is one of the high economic value of freshwater fish commodities in Indonesia. In order to increase aquaculture productivity, production of new generation from the best population was conducted to obtain a more productive and fast-growing generation. The purpose of this study was to evaluate the response and growth pattern of G-1, G-2, and G-3 fingerlings of Asian redtail catfish on different rearing media. The study was conducted in semi-permanent ponds, concrete ponds, and floating nets in Research Installation of Freshwater Fisheries Germplasm, Cijeruk with three replications. The stocking density of each treatment was $50 / \mathrm{m}^{2}$, with the fingerlings average length of $1.54 \pm 0.22 \mathrm{~cm}$ and weight of $0.06 \pm 0.01$. During the first 15 days, fish were fed with Tubifex and commercial feed ( $41 \%$ crude protein; fed $5 \%$ per day) with twice per day of feeding frequency. Fish were reared for 45 days, and growth measurement was conducted by sampling every 15 days. Parameters observed including specific growth rates, survival, and growth patterns. As supporting data, water quality, and plankton abundance were measured. The results showed that weight and length gain on the second generation (G-2) of Asian redtail catfish was

\footnotetext{
\# Korespondensi: Balai Riset Perikanan Budidaya Air Tawar dan

Penyuluhan Perikanan.

Jl. Sempur No. 1, Bogor 16129, Indonesia.

Tel. + 622518313200

E-mail: vitas.atmadi@gmail.com
} 
superior compared to G-1 and G-3, whilst the best rearing media was found in semi-permanent ponds with the weight of $6.79 \pm 4.085 \mathrm{~g}$ and the length of $8.46 \pm 1.967 \mathrm{~cm}$. The growth pattern of Asian redtail catfish from three rearing media was negative allometric $(b<3)$.

\section{KEYWORDS: Asian redtail catfish (Hemibagrus nemurus); growth pattern; survival rate; rearing media}

\section{PENDAHULUAN}

Ikan baung (Hemibagrus nemurus) di Jawa Barat kebanyakan disebut dengan ikan tagih, senggal, beong, dan nama populer "Asian redtail catfish" atau "River catfish" merupakan salah satu komoditas ikan air tawar ekonomis tinggi di Indonesia dan telah mendapatkan popularitas di kalangan konsumen dalam negeri, serta di wilayah Asia Tenggara (Handoyo et al., 2010). Balai Riset Perikanan Budidaya Air Tawar dan Penyuluhan Perikanan (BRPBATPP) telah melakukan domestikasi pada beberapa strain ikan baung yang berasal dari beberapa sumber (Sungai Cisadane, Sungai Serayu, Sungai Batanghari, dan Waduk Cirata).

Pengujian pada aspek bioreproduksi dan respons adaptasi pada lingkungan budidaya menghasilkan populasi dari Waduk Cirata sebagai kandidat budidaya terbaik. Populasi ikan baung Cirata memiliki fekunditas tinggi, diameter telur kecil, dan umur matang gonad awal lebih cepat dibandingkan dengan populasi lainnya (Subagja et al., 2015). Penggunaan populasi Cirata, diharapkan akan meningkatkan produktivitas benih ikan baung yang dihasilkan. Pembudidayaan ikan baung dapat membantu melestarikan sumber daya genetiknya, serta menambah jumlah komoditas potensial untuk usaha budidaya.

Pada tahun 2017, generasi kedua (G-2) populasi Cirata sudah mulai dewasa kelamin, sehingga dapat dipijahkan untuk memperoleh generasi ketiga (G-3). Sebagai generasi baru perlu adanya uji coba pengukuran dan pengamatan pertumbuhan dari generasi tersebut, dengan menyandingkan pemeliharaannya di beberapa wadah budidaya dengan dua generasi pendahulu (G-1 dan G-2). Pemeliharaan dilakukan pada waktu yang bersamaan dengan umur benih yang sama setiap generasi. Tujuan dari penelitian ini adalah untuk mengetahui respons dan pola pertumbuhan benih ikan baung G-1, G-2, dan G3 pada wadah budidaya yang berbeda.

\section{BAHAN DAN METODE}

Induk ikan baung G-0, G-1, dan G-2 dipijahkan dalam waktu yang bersamaan. Metode pemijahan untuk mendapatkan G-1, G-2, dan G-3 dilakukan menurut Kristanto et al. (2016). Induk yang digunakan dari setiap generasi masing-masing sebanyak tiga ekor betina dengan kisaran bobot 0,44-0,86 g per ekor dan tiga ekor induk jantan dengan bobot 0,6-0,8 kg per ekor. Induk jantan dan betina setiap generasi ditempatkan secara terpisah dalam wadah styrofoam.

Induk betina disuntik dengan hormon gonadotropin dengan dosis $0,6 \mathrm{~mL} / \mathrm{kg}$ dan diberikan dua kali suntikan dengan interval waktu delapan jam, suntikan pertama sebanyak $1 / 3$ dari total dosis dan suntikan terakhir $2 / 3$ dari dosis total. Induk jantan disuntik dengan dosis $0,3 \mathrm{~mL} / \mathrm{kg}$ dan diberikan pada saat bersamaan dengan induk betina yang menerima suntikan kedua. Pengecekan induk sebelum dilakukan stripping dilakukan setelah enam jam dari suntikan kedua. Induk jantan dibedah, diambil testisnya, kemudian digunting menjadi beberapa bagian berukuran kecil dan dimaserasi. Sperma yang diperoleh dicampurkan dengan $\mathrm{NaCl}$ fisiologis dalam wadah, sperma yang diperoleh dari ketiga induk jantan yang digunakan pada masing-masing generasi digabungkan menjadi satu sebelum digunakan untuk pembuahan sel telur. Telur-telur ikan baung yang telah dibuahi dari setiap generasi tersebut ditebar di dalam akuarium yang terpisah.

Setelah telur-telur tersebut menetas, benih yang dihasilkan dipelihara dalam akuarium. Umur tiga hari pascalarva diberi pakan Artemia tiga kali sehari secara at satiation sampai umur dua minggu, selanjutnya ditambah dengan cacing Tubifex dengan komposisi 1:1 sampai umur 20 hari. Selanjutnya setelah berumur 20 hari, benih masing-masing generasi dipelihara pada lingkungan wadah budidaya yang berbeda, yaitu: (a) kolam yang memiliki dasar tanah dengan dinding beton (semi-permanen) yang berukuran $8 \mathrm{~m} \times 5 \mathrm{~m} \times 1 \mathrm{~m}$, kolam ini disekat menjadi tiga bagian dengan menggunakan hapa; (b) kolam beton (permanen) berukuran $2 \mathrm{~m} \times 5 \mathrm{~m} \times 1 \mathrm{~m}$ yang disekat menjadi tiga bagian: dan (c) jaring apung berukuran $1 \mathrm{~m} \times 1 \mathrm{~m} \mathrm{x}$ $1 \mathrm{~m}$ yang dipasang pada rangka besi yang dipasang dalam kolam seluas $200 \mathrm{~m}^{2}$.

Rancangan percobaan dilakukan secara faktorial yang terdiri atas tiga perlakuan dan tiga ulangan dengan padat tebar masing-masing perlakuan 50 ekor/ $\mathrm{m}^{2}$. Panjang awal benih yang digunakan rata-rata 1,54 $\pm 0,22 \mathrm{~cm}$ dan bobot awal 0,06 $\pm 0,01 \mathrm{~g}$. Selama 15 hari pertama pemeliharaan di wadah budidaya benih ikan diberi pakan cacing Tubifex dan pakan komersial sebanyak 5\%dari biomassa dengan perbandingan 1:1, sedangkan frekuensi pemberian pakan dua kali sehari 
yang dilakukan pada pagi dan sore hari. Selanjutnya selama masa pemeliharaan benih diberi pakan komersil tanpa kombinasi dengan dosis dan frekuensi yang sama dengan sebelumnya.

Pemeliharaan benih ikan baung dilakukan selama 45 hari, dan untuk mengetahui pertumbuhan dilakukan sampling setiap 15 hari sekali. Pengambilan ikan sampel dilakukan secara acak sebanyak 30\%dari setiap ulangan. Parameter yang yang diukur meliputi panjang total, panjang standar, bobot individu ikan sampel, serta sintasan. Data yang telah diperoleh kemudian ditabulasi dan dianalisis menggunakan program Microsoft Excel 2010 dan analisis ANOVA faktorial SPSS 22. Dari analisis data yang tersebut di atas dapat diketahui pertumbuhan mutlak, laju pertumbuhan harian, dan pola pertumbuhan ikan baung masingmasing generasi yang digambarkan melalui hubungan panjang dan bobot ikan.

Laju pertumbuhan spesifik dihitung berdasarkan rumus Weatherley \& Gill (1987), sintasan dihitung berdasarkan rumus Mudjiman (2004), dan Hubungan panjang-bobot menggunakan rumus Effendie (1975). Untuk mengetahui kualitas dan tingkat kesuburan media pemeliharaan dilakukan pengukuran kualitas air dan penghitungan kelimpahan plankton tiap-tiap wadah pemeliharaan. Untuk pengukuran fisika dan kimia air dilakukan dengan cara mengambil air sampel kolam tiap-tiap wadah pemeliharan, air sampel diambil dari lima titik di setiap perlakuan yang kemudian dimasukkan ke dalam botol sampel yang telah diberi label Ialu disimpan dalam coolbox. Analisis kimia air ( $\mathrm{pH}$, nitrit, nitrat, dan TAN) dilakukan di Laboratorium Lingkungan dan Toksikologi, Cibalagung; sedangkan fisika air seperti suhu dilakukan langsung ditempat dengan menggukan DO meter, pada empat waktu pengamatan, yaitu: sebelum matahari terbit, setelah matahari terbit, siang hari, dan setelah matahari terbenam.

Selanjutnya untuk mengetahui kesuburan media pemeliharaan sebagai daya dukung lingkungan dilakukan pengamatan dan penghitungan kelimpahan plankton, baik berupa fitoplankton maupun zooplankton. Dari setiap wadah pemeliharan dilakukan pengambilan air sampel dari lima titik, di setiap titik dilakukan pengambilan air sebanyak $10 \mathrm{~L}$ yang kemudian disaring dengan menggunakan plankton net. Air yang tersaring $(100 \mathrm{~mL})$ dimasukkan ke dalam botol sampel dan diberi alkohol 2-3 tetes supaya sampel tidak rusak. Pengamatan jenis plankton dilakukan di laboratorium Nutrisi BRPBATPP Sempur, Bogor. Untuk mengetahui po pulasi plankton dilakukan penghitungan dengan metode kelimpahan plankton (Sachlan, 1982).

\section{HASIL DAN BAHASAN}

Pertumbuhan bobot dan panjang benih ikan baung G-1, G-2, dan G-3 yang dipelihara di kolam semipermanen, kolam beton, dan jaring apung pada umur 65 hari menunjukkan bahwa bobot maupun panjang benih G-2 lebih unggul dibandingkan dengan benih G-1 dan G-3 (Tabel 1). Dari analisis statistik faktorial (Gambar 1) G-2 beda nyata $(P<0,05)$ terhadap $\mathrm{G}-1$ dan G-3. Sementara itu, wadah budidaya yang terbaik adalah pada pemeliharaan di kolam semi-permanen dengan bobot 6,79 \pm 4,08 $\mathrm{g}$ dan panjang $8,46 \pm 1,97$ $\mathrm{cm}$. Perlakuan pemeliharaan di kolam semi-permanen menunjukkan perbedaan yang nyata $(P<0,05)$ dibandingkan dengan pemeliharaan di hapa dan kolam beton (Tabel 1) (Gambar 1 dan 2). Hal ini diduga karena kolam semi-permanen selain kaya nutrisi, ikan baung juga lebih menyukai perairan yang tenang dan berlumpur, sebagai bentuk kebiasaannya yang suka berada di dasar kolam sebagaimana ikan sejenisnya yang bersifat nokturnal.

Laju pertumbuhan spesifik (Tabel 2) pada pemeliharaan di kolam semi-permanen menunjukkan bahwa benih ikan baung G-2 mempunyai nilai yang tertinggi dengan berbeda nyata $(P<0,05)$ terhadap G-1 dan G-3.

Pertumbuhan ikan erat kaitannya dengan hubungan panjang dan bobot, berdasarkan pengamatan dan pengukuran secara fisik parameter ini dapat menggambarkan kondisi ikan. Hubungan panjang dan bobot ikan yang telah diketahui, maka dapat ditentukan pola pertumbuhan, serta pertumbuhan prediksi dari suatu jenis ikan, lalu membandingkan dengan hasil pertumbuhan ikan terukur. Hubungan panjang-bobot ikan (Gambar 3) menunjukkan nilai b untuk struktur dan tipe wadah budidaya yang berbeda tidaklah sama. Rata-rata nilai b dari ketiga generasi Ikan baung yang dipelihara di kolam semi-permanen adalah 2,94 sedangkan pada kolam beton dan jaring nilai rata-ratanya yaitu 2,70 dan 2,55 . Berdasarkan nilai tersebut, dapat diartikan bahwa pola pertumbuhan ikan dapat dipengaruhi oleh kondisi perairan, tipe wadah pemeliharaan, dan faktor genetik. Meskipun nilai $b$ untuk keduanya berada di bawah nilai tiga, namun pemeliharaan pada kolam semi permanen lebih mendekati ke arah pertumbuhan yang seimbang antara panjang dan bobot ikan (isometrik). Pola pertumbuhan benih ikan baung pada tiga generasi pada kolam beton memperlihatkan pola yang sama, demikian juga pada kolam semi-permanen, sedangkan pada pemeliharaan di jaring pada antar generasi menunjukkan grafik pola yang berbeda (Gambar 3). Secara umum nilai $b$ tergantung pada kondisi fisiologis 
Tabel 1. Pertumbuhan benih ikan baung (Hemibagrus nemurus) G-1, G-2, dan G-3 pada wadah budidaya yang berbeda saat umur 65 hari dari menetas

Table 1. Growth of seedlings of Asian redtail catfish (Hemibagrus nemurus) G-1, G-2, and G3 on different of rearing culture media at the age of 65 days after hatching

\begin{tabular}{|c|c|c|c|c|}
\hline \multirow{2}{*}{$\begin{array}{l}\text { Wadah budidaya } \\
\text { Cultured media }\end{array}$} & \multirow{2}{*}{$\begin{array}{c}\text { Periode } \\
\text { pemeliharaan (hari) } \\
\text { Period of maintenance (days) }\end{array}$} & \multirow{2}{*}{$\begin{array}{l}\text { Generasi } \\
\text { Generation }\end{array}$} & \multicolumn{2}{|c|}{ Pertumbuhan (Growth ) } \\
\hline & & & $\begin{array}{c}\text { Bobot } \\
\text { Weight (g) }\end{array}$ & $\begin{array}{c}\text { Panjang total } \\
\text { Total length }(\mathrm{cm})\end{array}$ \\
\hline \multirow{9}{*}{$\begin{array}{l}\text { Kolam beton } \\
\text { Concrete ponds }\end{array}$} & 15 & \multirow{3}{*}{1} & $0.67 \pm 0.268$ & $3.97 \pm 0.497$ \\
\hline & 30 & & $1.07 \pm 0.418$ & $4.84 \pm 0.638$ \\
\hline & 45 & & $1.69 \pm 0.748$ & $5.54 \pm 0.741$ \\
\hline & 15 & \multirow{3}{*}{2} & $0.68 \pm 0.154$ & $4.04 \pm 0.385$ \\
\hline & 30 & & $1.08 \pm 0.203$ & $4.92 \pm 0.361$ \\
\hline & 45 & & $1.90 \pm 0.249$ & $5.81 \pm 0.334$ \\
\hline & 15 & \multirow{3}{*}{3} & $0.63 \pm 0.185$ & $3.84 \pm 0.422$ \\
\hline & 30 & & $1.11 \pm 0.280$ & $4.81 \pm 0.456$ \\
\hline & 45 & & $1.23 \pm 0.186$ & $5.04 \pm 0.292$ \\
\hline \multirow{9}{*}{$\begin{array}{l}\text { Kolam semi-permanen } \\
\text { Semi-permanent ponds }\end{array}$} & 15 & \multirow{3}{*}{1} & $0.46 \pm 0.273$ & $3.54 \pm 0.614$ \\
\hline & 30 & & $1.23 \pm 0.446$ & $5.02 \pm 0.640$ \\
\hline & 45 & & $3.99 \pm 3.588$ & $7.05 \pm 1.789$ \\
\hline & 15 & \multirow{3}{*}{2} & $0.55 \pm 0.226$ & $3.68 \pm 0.545$ \\
\hline & 30 & & $1.36 \pm 0.622$ & $5.03 \pm 0.667$ \\
\hline & 45 & & $6.79 \pm 4.085^{*}$ & $8.46 \pm 1.967^{*}$ \\
\hline & 15 & \multirow{3}{*}{3} & $0.38 \pm 0.131$ & $3.25 \pm 0.374$ \\
\hline & 30 & & $1.43 \pm 0.501$ & $5.15 \pm 0.681$ \\
\hline & 45 & & $3.97 \pm 4.630$ & $6.71 \pm 1.838$ \\
\hline \multirow{9}{*}{$\begin{array}{l}\text { Jaring apung } \\
\text { Floating net cages }\end{array}$} & 15 & \multirow{3}{*}{1} & $0.30 \pm 0.273$ & $2.88 \pm 0.698$ \\
\hline & 30 & & $1.22 \pm 0.437$ & $4.69 \pm 0.803$ \\
\hline & 45 & & $1.92 \pm 0.00$ & $6.00 \pm 0.00$ \\
\hline & 15 & \multirow{3}{*}{2} & $0.24 \pm 0.089$ & $2.88 \pm 0.347$ \\
\hline & 30 & & $0.32 \pm 0.075$ & $3.31 \pm 0.279$ \\
\hline & 45 & & $1.82 \pm 0.126$ & $5.53 \pm 0.255$ \\
\hline & 15 & \multirow{3}{*}{3} & $0.23 \pm 0.078$ & $3.23 \pm 2.360$ \\
\hline & 30 & & $0.28 \pm 0.046$ & $3.14 \pm 0.187$ \\
\hline & 45 & & $0.52 \pm 0.111$ & $3.84 \pm 0.326$ \\
\hline
\end{tabular}

Keterangan (Descriptions): * menunjukkan perbedaan yang nyata $(P<0,05)$ (showed significant differences $(P<0.05))$

dan lingkungan seperti suhu, pH, salinitas, letak geografis, teknik sampling, dan ketersediaan makanan (Jenning et al., 2001; Froese, 2006). Dari analisis nilai b maka, ikan baung dapat dikategorikan sebagai ikan yang memiliki pola pertumbuhan allometrik negatif. Jadi nilai b tidak hanya dipengaruhi oleh faktor internal dan eksternal tapi juga dipengaruhi oleh jenis ikan. Nilai regresi dari ketiga generasi dari setiap struktur dan tipe wadah budidaya mendekati satu, nilai ini menunjukkan keeratan antara hubungan panjang dan bobot ikan sekaligus dapat mengambarkan bahwa keragaman yang dipengaruhi oleh variabel lain cukup kecil. Walpole (1995) melaporkan bahwa jika nilai ( $\left.{ }^{2}\right)$ mendekati satu, maka terdapat hubungan yang kuat antara kedua variabel tersebut.

Berdasarkan penelitian ini, kondisi optimal bagi laju pertumbuhan dan pola pertumbuhan yang seimbang antara panjang dan bobot benih ikan baung yaitu pada kolam semi-permanen. Faktor lingkungan seperti biologi dan fisiologi ikan, maternal efek, pola 


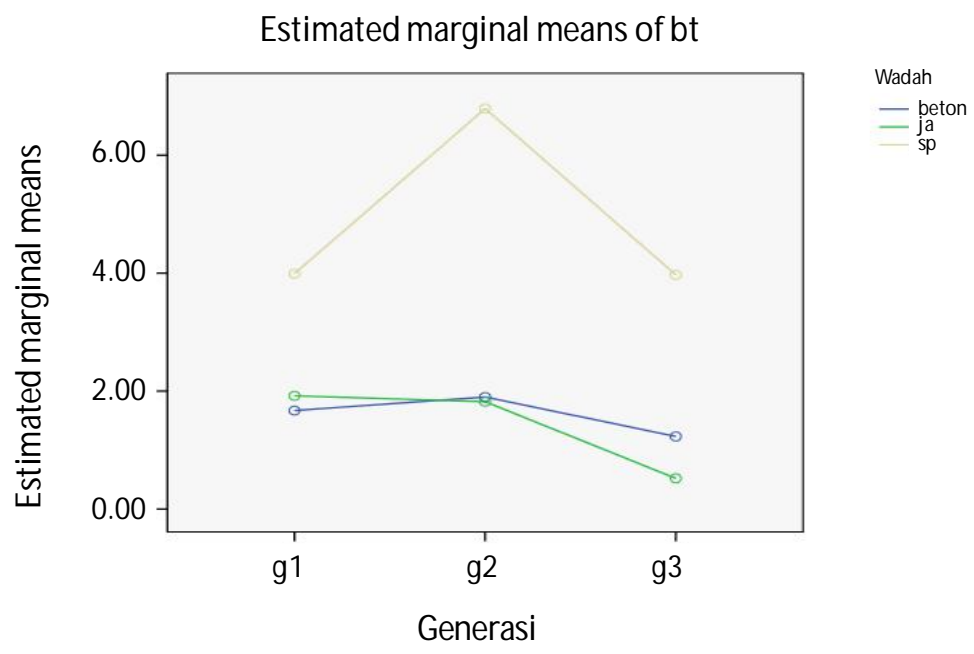

Gambar 1. Estimasi nilai marginal rata-rata dari bobot.

Figure 1. Estimated marginal means of weight.

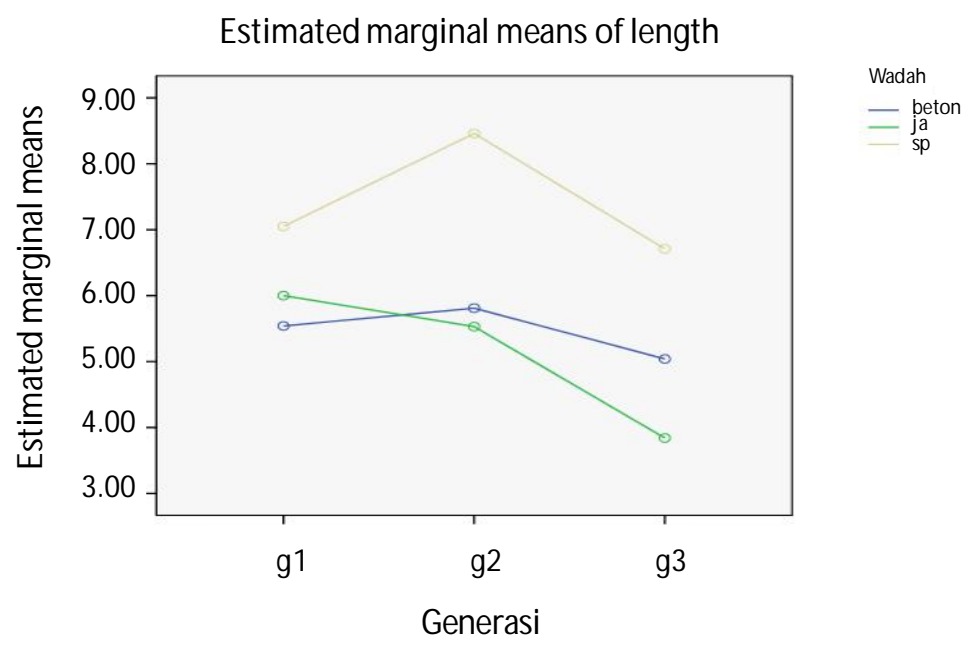

Gambar 2. Estimasi nilai marginal rata-rata dari panjang.

Figure 2. Estimated marginal means of length.

makan, dan kompensasi pertumbuhan akan memengaruhi fenotipe suatu individu atau populasi ikan. Pada pemeliharaan di kolam semi-permanen umumnya selain kelimpahan plankton juga banyak mengandung mikroorganisme yang kaya akan nutrisi untuk benih, sehingga pertumbuhan ikannya dapat optimal. Sedangkan dari segi wadah pemeliharaan, yang paling kecil sintasannya adalah yang dipelihara di kolam semi permanen $(1,51 \%$, kelemahan pemeliharaan di kolam semi-permanen selain hama yang masuk susah dikontrol juga rentan terkena penyakit seperti jamur, virus, dan bakteri yang ada pada tanah sehingga menyebabkan sintasan yang rendah jika dibandingkan dengan wadah pemeliharaan yang lain. Pada kolam beton dan jaring hama yang masuk mudah terkontrol sehingga tingkat kematiannya lebih rendah dibandingkan dengan pemeliharaan di kolam semipermanen. Hal ini menunjukkan bahwa pertumbuhan bobot berbanding terbalik dengan sintasan, terlihat pada pertumbuhan bobot dan panjang pada pemeliharaan semi-permanen yang cukup tinggi namun sintasannya rendah. Sintasan G-3 secara keseluruhan dipelihara di kolam beton, semipermanen dan hapa $28,17 \%$ (rata-rata 9,39\% lebih unggul jika dibandingkan dengan G-1: 14,27\% (ratarata 4,76\% dan G-2: 13,96\%(rata-rata 4,65\% (Tabel 3). Dari analisis statistik faktorial diketahui bahwa keragaman berbeda secara signifikan namun tidak homogen, dan terdapat perbedaan sintasan yang nyata antar generasi setiap wadah. Tidak terdapat interaksi antara wadah pemeliharaan, generasi, dan sintasan (Gambar 4). Produktivitas benih ikan baung yang 
Tabel 2. Pertambahan bobot dan laju pertumbuhan spesifik benih ikan baung (Hemibagrus nemurus) G-1, G-2, dan G-3 pada wadah budidaya yang berbeda saat umur 65 hari dari menetas

Table 2. Weight gain and specific growth rate on seedlings of Asian redtail catfish (Hemibagrus nemurus) G-1, G-2, and G-3 on different rearing culture media at the age of 65 days after hatching

\begin{tabular}{cccc}
\hline $\begin{array}{c}\text { Generasi } \\
\text { Generation }\end{array}$ & $\begin{array}{c}\text { Wadah pemeliharaan } \\
\text { Rearing media }\end{array}$ & $\begin{array}{c}\text { Pertambahan bobot } \\
\text { Weight gain (g) }\end{array}$ & $\begin{array}{c}\text { Laju pertumbuhan spesifik (\%hari) } \\
\text { Specific growth rate (\%/day) }\end{array}$ \\
\hline 1 & Kolam beton & $1.63 \pm 0.515$ & $7.04 \pm 0.703$ \\
2 & Concrete ponds & $1.85 \pm 0.849$ & $7.89 \pm 1.047$ \\
3 & $1.17 \pm 0.374$ & $6.35 \pm 0.609$ \\
\hline 1 & Kolam semi-permanen & $3.92 \pm 1.598$ & $8.80 \pm 1.130$ \\
2 & Semi-permanent ponds & $6.74 \pm 3.714$ & $10.59 \pm 1.312 *$ \\
3 & & $3.90 \pm 1.147$ & $8.93 \pm 0.693$ \\
\hline 1 & & $1.85 \pm 0.600$ & $7.30 \pm 0.739$ \\
2 & Jaring apung & $1.77 \pm 1.419$ & $7.40 \pm 1.617$ \\
3 & Floating nets & $0.45 \pm 0.185$ & $4.38 \pm 0.775$ \\
\hline
\end{tabular}

Keterangan: * menunjukkan perbedaan yang nyata $(\mathrm{P}<0,05)$

Descriptions: * showed significant differences $(P<0.05)$

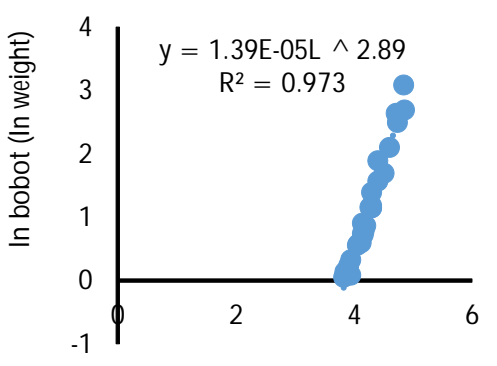

In panjang total (In total length)

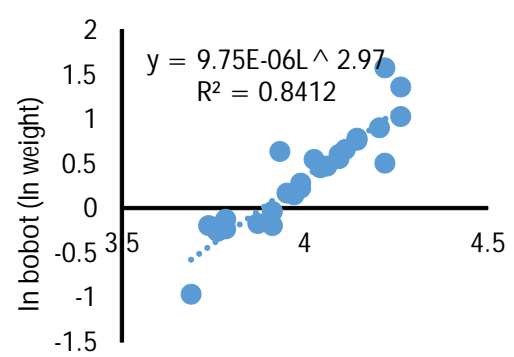

In panjang total (In total length)

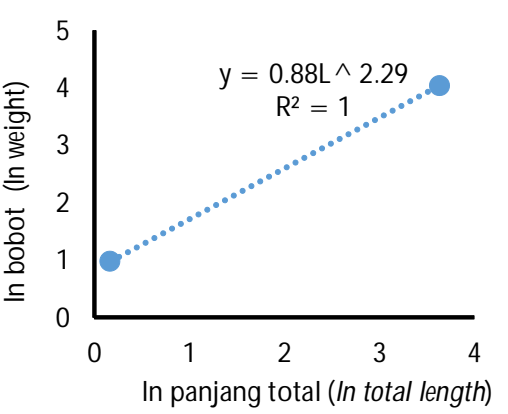

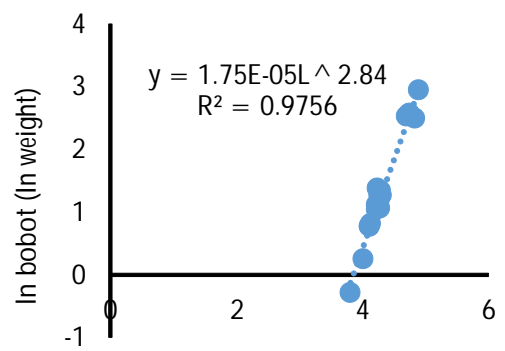

In panjang total (In total length)

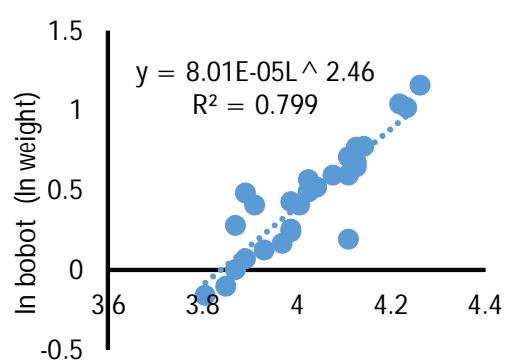

In panjang total (In total length)

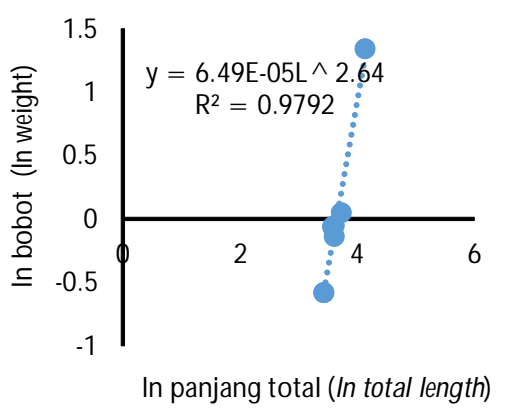

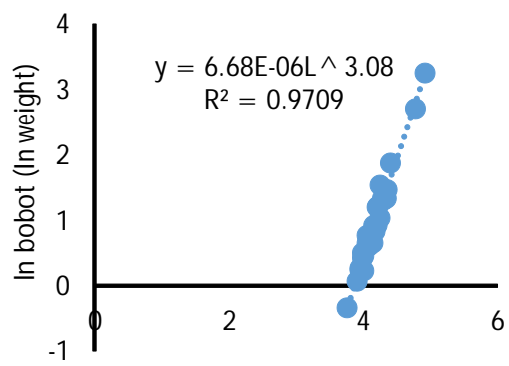

In panjang total (In total length)

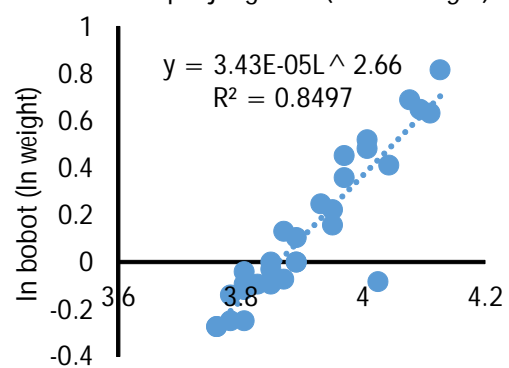

In panjang total (In total length)

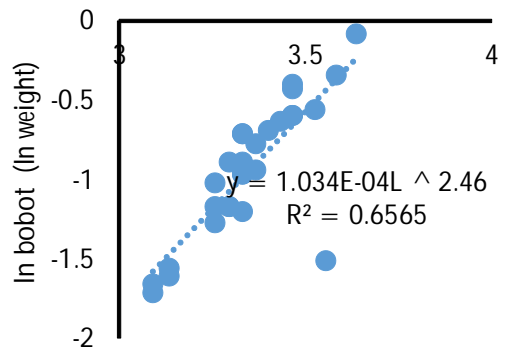

In panjang total (In total length)

Gambar 3. Hubungan panjang dan bobot ikan baung (Hemibagrus nemurus) G-1, G-2, dan G-3 pada wadah budidaya yang berbeda (A. kolam beton; B. kolam semi-permanen, dan $C$. jaring apung).

Figure 3. Length-weight relationships on seedlings of Asian redtail catfish (Hemibagrus nemurus) G-1, G-2, and G3 on different rearing media (A. concrete ponds; $B$. semi-permanent ponds, and $C$. in floating nets). 
Tabel 3. Sintasan benih ikan baung (Hemibagrus nemurus) G-1, G-2, dan G-3 pada wadah budidaya yang berbeda

Table 3. Survival rate on seedlings of Asian redtail catfish (Hemibagrus nemurus) G-1, G-2, and G-3 on different rearing culture media

\begin{tabular}{cccc}
\hline \multirow{2}{*}{$\begin{array}{c}\text { Generasi } \\
\text { Generation }\end{array}$} & $\begin{array}{c}\text { Kolam beton } \\
\text { Concrete ponds }\end{array}$ & $\begin{array}{c}\text { Kolam semi-permanen } \\
\text { Semi-permanent ponds }\end{array}$ & $\begin{array}{c}\text { Jaring apung } \\
\text { Floating net cages }\end{array}$ \\
\cline { 2 - 4 } & $9.78 \pm 4.36$ & $2.49 \pm 1.42$ & $2.00 \pm 0.00$ \\
G-1 & $7.78 \pm 4.76$ & $1.51 \pm 0.55$ & $4.67 \pm 1.88$ \\
G-3 & $6.66 \pm 4.99$ & $2.84 \pm 0.76$ & $18.67 \pm 9.84$ \\
\hline
\end{tabular}

dipelihara di hapa untuk G-3: $12,6 \mathrm{~g} / \mathrm{m}^{2} ; \mathrm{G}-2: 12,39 \mathrm{~g} /$ $\mathrm{m}^{2}$; dan G-1: $3,7 \mathrm{~g} / \mathrm{m}^{2}$. Tingginya nilai produktivitas pada G-3 disebabkan sintasan yang lebih tinggi, meskipun pertumbuhan individu G-3 cukup rendah.

Pada kondisi optimal, metabolisme dan nafsu makan ikan meningkat, sehingga akan berpengaruh positif terhadap pertumbuhan (Kusakabe et al., 2017). Menurut Salari et al. (2012), faktor interaksi, kualitas air, dan kondisi lingkungan pemeliharaan ikan harus dipelajari untuk tercapainya efisiensi produktivitas budidaya. Informasi mengenai sistem pemeliharaan yang optimal bagi benih ikan baung ini dapat menjadi informasi yang sangat berguna untuk aplikasi budidaya.

Faktor penting yang memengaruhi tingkat sintasan ikan adalah kualitas air, terutama suhu. Suhu dapat mengurangi kadar oksigen terlarut dalam air jika jangkauannya tidak optimal. Suhu dapat memengaruhi pernapasan ikan (Emaliana et al., 2016). Sementara menurut Murjani (2011), sintasan ikan tergantung pada adaptasi ikan terhadap lingkungan dan kualitas air. Dari hasil pengukuran oksigen terlarut dan suhu air kolam saat penelitian berlangsung diketahui kisaran oksigen terlarut sebelum matahari terbit untuk ketiga struktur wadah budidaya $4,28-5,27 \mathrm{mg} . \mathrm{L}^{-1}$ dengan suhu $22,3^{\circ} \mathrm{C}$ $23,3^{\circ} \mathrm{C}$; setelah matahari terbit oksigen terlarut sebesar 5,21-6,8 mg. $\mathrm{L}^{-1}$ suhu $23,4^{\circ} \mathrm{C}-24,3^{\circ} \mathrm{C}$; saat siang hari oksigen terlarut sebesar 7,94-11,18 mg. $\mathrm{L}^{-1}$ dengan kisaran suhu $25,4^{\circ} \mathrm{C}-28,1^{\circ} \mathrm{C}$ dan setelah matahari terbenam kadar oksigen terlarut sebesar 5,09-7,95 mg. $\mathrm{L}^{-1}$ dengan suhu rata-rata $23,4^{\circ} \mathrm{C}-25,8^{\circ} \mathrm{C}$ (Tabel 4). Kandungan nitrit, nitrat, dan TAN (Tabel 5).

Suhu memengaruhi pertumbuhan dan nafsu makan ikan (Effendi, 2003). Menurut Primaningtyas et al. (2015), kenaikan suhu akan menyebabkan turunnya daya larut oksigen dalam air, namun kenyataan di lapangan pada siang hari saat kondisi suhu paling tinggi nilai kandungan oksigen terlarut menunjukkan angka tertinggi dibanding saat suhu rendah. Penyimpangan ini diduga karena adanya aktivitas fotosintesis yang dialami oleh lumut ataupun alga yang banyak tumbuh di dalam kolam. Dengan adanya aktivitas fotosintesis akan menyebabkan surplus oksigen terlarut sedangkan

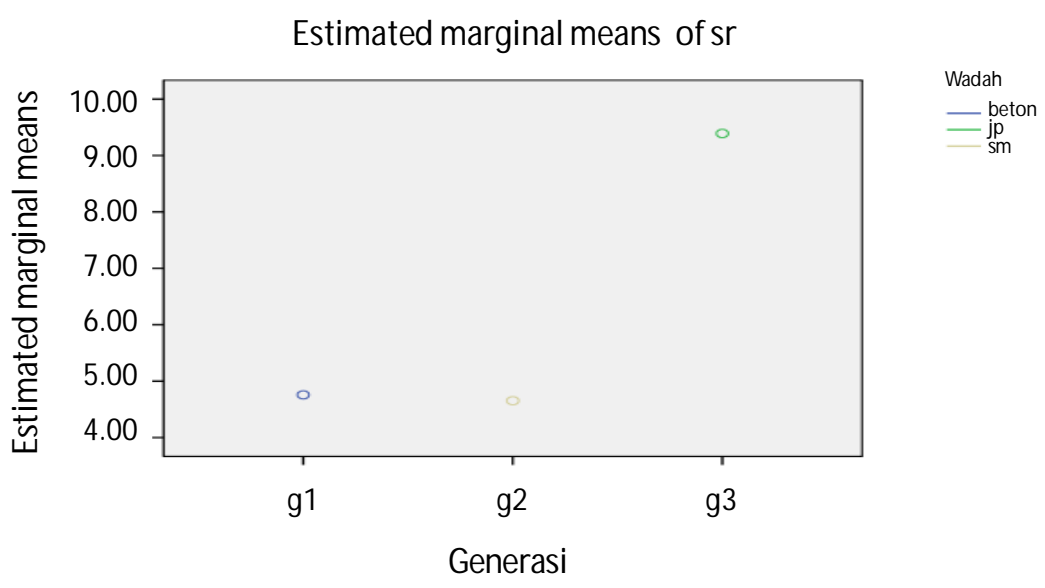

Non-estimable means are not plotted

Gambar 4. Perkiraan nilai marginal rata-rata sintasan.

Figure 4. Estimated marginal means of survival rate. 
Tabel 4. Kualitas air (parameter fisika) media pemeliharaan benih ikan baung pada tiga wadah budidaya Table 4. Water quality (physical parameters) on rearing media of Asian redtail catfish (Hemibagrus nemurus) seedlings on three of rearing culture media

\begin{tabular}{|c|c|c|c|c|c|c|c|}
\hline \multirow{4}{*}{$\begin{array}{l}\text { Waktu (jam) } \\
\text { Time (hour) }\end{array}$} & \multirow{4}{*}{$\begin{array}{l}\text { Lokasi } \\
\text { Location }\end{array}$} & \multicolumn{6}{|c|}{ Wadah budidaya (Rearing media ) } \\
\hline & & \multicolumn{2}{|c|}{$\begin{array}{l}\text { Kolam beton } \\
\text { Concrete ponds }\end{array}$} & \multicolumn{2}{|c|}{$\begin{array}{l}\text { Kolam semi-permanen } \\
\text { Semi-permanent ponds }\end{array}$} & \multicolumn{2}{|c|}{$\begin{array}{l}\text { Jaring apung } \\
\text { Floating net cages }\end{array}$} \\
\hline & & \multicolumn{6}{|c|}{ Parameter (Parameters) } \\
\hline & & $\begin{array}{l}\text { Oksigen terlarut } \\
\text { Dissolved oxygen } \\
\text { (mg/L) }\end{array}$ & $\begin{array}{c}\text { Suhu } \\
\text { Temperature } \\
\left.\text { ( }{ }^{\circ} \mathrm{C}\right)\end{array}$ & $\begin{array}{c}\text { Oksigen terlarut } \\
\text { Dissolved oxygen } \\
\text { (mg/L) }\end{array}$ & $\begin{array}{c}\text { Suhu } \\
\text { Temperature } \\
\left({ }^{\circ} \mathrm{C}\right)\end{array}$ & $\begin{array}{c}\text { Oksigen terlarut } \\
\text { Dissolved oxygen } \\
\text { (mg/L) }\end{array}$ & $\begin{array}{c}\text { Suhu } \\
\text { Temperature } \\
\text { ( } \mathrm{C} \text { C) }\end{array}$ \\
\hline \multirow{2}{*}{ 05.00-05.30 WIB } & Inlet & 4.46 & 23.3 & 4.53 & 22.3 & 5.27 & 22.9 \\
\hline & Outlet & 4.28 & 22.8 & 4.4 & 22.4 & 4.45 & 23.1 \\
\hline \multirow{2}{*}{ 08.35-09.00 WIB } & Inlet & 6.8 & 23.6 & 5.63 & 23.9 & 6.01 & 24.3 \\
\hline & Outlet & 5.7 & 23.4 & 5.8 & 23.4 & 5.21 & 24.2 \\
\hline \multirow{2}{*}{$13.27-14.00$ WIB } & Inlet & 11.1 & 27.9 & 10.6 & 26.6 & 9.32 & 27.2 \\
\hline & Outlet & 11.1 & 28.1 & 11.18 & 25.4 & 7.94 & 27.1 \\
\hline \multirow{2}{*}{$18.47-19.20$ WIB } & Inlet & 7.95 & 25.8 & 6.07 & 24.5 & 6.43 & 25.3 \\
\hline & Outlet & 6.04 & 25.6 & 5.09 & 23.4 & 6.36 & 25.4 \\
\hline
\end{tabular}

Tabel 5. Kualitas air (parameter kimia) media pemeliharaan benih ikan baung pada tiga struktur wadah budidaya

Table 5. Water quality (chemical parameters) on rearing media of Asian redtail catfish (Hemibagrus nemurus) on three types of rearing culture media

\begin{tabular}{lccc}
\hline \multirow{2}{*}{$\begin{array}{c}\text { Parameter } \\
\text { Parameters }\end{array}$} & \multicolumn{3}{c}{ Wadah budidaya (Rearing media ) } \\
\cline { 2 - 4 } & $\begin{array}{c}\text { Kolam beton } \\
\text { Concrete ponds }\end{array}$ & $\begin{array}{c}\text { Kolam semi-permanen } \\
\text { Semi-permanent ponds }\end{array}$ & $\begin{array}{c}\text { Jaring apung } \\
\text { Floating net cages }\end{array}$ \\
\hline $\begin{array}{l}\text { Nitrit } \\
\text { Nitrite }\end{array}$ & 0.0076 & 0.0076 & 0.0076 \\
$\begin{array}{l}\text { Nitrat } \\
\text { Nitrate }\end{array}$ & 2.3 & 5.6 & 5.6 \\
TAN & 0.08 & 0.08 & 0.08 \\
\hline
\end{tabular}

menurunnya oksigen terlarut pada saat suhu rendah sebelum matahari terbit disebabkan karena aktivitas fotosintesis yang belum berjalan sedangkan tumbuhan lumut ataupun alga sama-sama membutuhkan oksigen terlarut untuk proses kehidupannya.

Nitrogen anorganik terdiri atas amonia $\left(\mathrm{NH}_{3}\right)$, amonium $\left(\mathrm{NH}_{4}^{+}\right)$, nitrit $\left(\mathrm{NO}_{2}^{-}\right)$, nitrat $\left(\mathrm{NO}_{3}^{-}\right)$, dan molekul nitrogen $\left(\mathrm{N}_{2}\right)$. Tingginya konsentrasi nitrogen anorganik akan menambah kesuburan kolam dan dalam waktu cepat dapat menurunkan kualitas air kolam (Effendi, 2003). Kandungan total amonia nitrogen hasil pengukuran masih dalam konteks yang wajar dan layak digunakan untuk budidaya ikan. Zat hara anorganik utama yang diperlukan oleh fitoplankton untuk tumbuh dan berkembang biak adalah nitrogen sebagai nitrat $\left(\mathrm{NO}_{3}{ }^{-}\right)$. Nitrat dapat dimanfaatkan/ diserap oleh tumbuhan air dan fitoplankton untuk pertumbuhannya sehingga kadar nitrat dapat berkurang dalam kolam atau badan perairan. Namun nilai nitrat yang sangat tinggi dalam penelitian ini akibat penyerapan nitrat yang ada hanya dimanfaatkan oleh fitoplankton dan tumbuhan tingkat rendah saja seperti lumut untuk pertumbuhan dan perkembangbiakannya, sedangkan jumlah individu 
maupun biodiversity fitoplankton di kolam sangat sedikit maka nitrat yang terserap tidak banyak sehingga mengakibatkan kadar nitrat di kolam lebih tinggi. Selain itu, tingginya kandungan nitrat diduga minimnya penguraian yang dilakukan oleh mikroorganisme akuatik. Meskipun nilai nitrat cukup tinggi namun kondisi perairan kolam masih dapat dikategorikan layak guna untuk kegiatan budidaya sesuai standar baku mutu kualitas air, menurut PP. No. 82 Tahun 2001 (Tabel 6).

Produktivitas perairan biasanya akan bersifat linear terhadap kandungan bahan organik, dan diprediksi bahwa sisa pakan ataupun kotoran ikan tidak signifikan dapat memengaruhi unsur organik dalam kolam, diduga karena pemberian pakan yang ditimbang sesuai dengan kebutuhan bobot biomassa sehingga kemungkinan tumpukan sisa pakan di dasar kolam sangat kecil dan ukuran ikan pun masih kecil sehingga tidak begitu besar memberi kontribusi terhadap tumpukan bahan organik berupa kotoran di dalam kolam. Hal ini dapat terlihat dari hasil pengamatan kelimpahan dan biodiversity plankton, dari ketiga struktur kolam pemeliharaan kelimpahan plankton menunjukkan nilai indeks di bawah 2.000 individu/L (87-123 individu/L) (Tabel 7). Tingkat kesuburan kolam dapat kita lihat dari jumlah dan jenis plankton yang terdapat di dalam kolam, sebab kelimpahan jasad renik tersebut sangat bergantung pada kandungan nutrien atau bahan organik yang terdapat di dalam kolam. Nutrien/bahan organik ini dapat berasal dari pengikisan daratan yang terbawa oleh aliran sungai yang masuk mengairi kolam ataupun berasal dari kolam itu sendiri yang berupa sisa pakan dan kotoran ikan. Tabel 7, memperlihatkan kelimpahan plankton per liter yang terbanyak adalah pada struktur budidaya di jaring, serta jenis plankton rotifera sebagai makanan benih baung lebih banyak daripada di kolam semi-permanen dan di kolam beton, hal ini berkenaan dengan tingginya kandungan nitrat yang merupakan sumber nutrien utama untuk pertumbuhannya. Diduga kandungan nitrat dalam kolam tempat pemasangan jaring apung lebih konstan dibanding pada kolam semi-permanen, yang setiap saat sampling dilakukan pengurasan air kolam. Kondisi ini secara langsung akan berpengaruh pada sintasan benih baung, sintasan benih yang tertinggi ada pada pemeliharaan di jaring $(25,34 \%$. Pada pemeliharaan di jaring selain hama yang mudah dikontrol juga ketersediaan pakan yang banyak untuk benih ikan baung sehingga sintasannya lebih tinggi. Menurut Effendi (2003), sintasan benih ikan ditentukan oleh kualitas induk, kualitas telur, kualitas air, serta perbandingan antara jumlah makanan dan kepadatannya.

Yuningsih et al. (2014) mengemukakan bahwa komposisi bahan organik yang tinggi dapat menyebabkan pertumbuhan bakteri dan fitoplankton tinggi, dan menurut Soedarti et al. (2006), munculnya fitoplankton yang dominan dan tidak dominan dalam suatu komunitas perairan menyebabkan perairan tersebut tidak seimbang akibat pencemaran dari buangan limbah ke perairan. Berdasarkan dari beberapa parameter di atas maka dapat dikatakan bahwa kondisi perairan kurang menguntungkan bahkan dapat dikatakan kurang produktif.

\section{KESIMPULAN}

Pemilihan wadah budidaya yang tepat dapat meningkatkan produktivitas ikan baung secara signifikan. Sebagai ikan bentik/suka hidup di dasar perairan pertumbuhan ikan baung lebih optimal jika dipelihara pada kolam semi-permanen.

Tabel 6. Perbandingan nilai kualitas air menurut standar baku mutu PP. No. 82 Tahun 2001

Table 6. Comparison of water quality according to PP. No. 82, 2001 about standard of water quality

\begin{tabular}{lcc}
\hline \multicolumn{1}{c}{$\begin{array}{c}\text { Parameter } \\
\text { Parameters }\end{array}$} & $\begin{array}{c}\text { Standar baku mutu PP No. 82 Tahun 2001 } \\
\text { untuk kegiatan budidaya ikan air tawar (kelas II) } \\
\text { Water quality standard from PP. 82, 2001 } \\
\text { for freshwater aquaculture (class II) }\end{array}$ & $\begin{array}{c}\text { Perairan yang baik untuk menunjang } \\
\text { kegiatan budidaya ikan air tawar } \\
\text { Optimal water quality to support } \\
\text { freshwater aquaculture activities }\end{array}$ \\
\hline $\begin{array}{l}\text { Suhu } \\
\text { Temperature }\left({ }^{\circ} \mathrm{C}\right) \\
\text { Oksigen terlarut } \\
\text { Dissolved oxygen }\left(\mathrm{mg} . \mathrm{L}^{-1}\right)\end{array}$ & Deviasi-3 (Deviation-3) \\
Nitrat & 4 & $28-32$ \\
Nitrate (mg.L-1) & 10 & $? 5$ \\
\hline
\end{tabular}


Tabel 7. Kelimpahan plankton pada tiga struktur wadah budidaya pemeliharaan benih ikan baung (Hemibagrus nemurus)

Table 7. Plankton abundance on three types of rearing culture media of Asian redtail catfish (Hemibagrus nemurus)

\begin{tabular}{|c|c|c|c|}
\hline \multirow{2}{*}{$\begin{array}{l}\text { Plankton } \\
\text { Plankton }\end{array}$} & \multicolumn{3}{|c|}{ Kelimpahan (individu/L) / Abundance (individual/L) } \\
\hline & $\begin{array}{l}\text { Kolam beton } \\
\text { Concrete ponds }\end{array}$ & $\begin{array}{l}\text { Kolam semi-permanen } \\
\text { Semi-permanent ponds }\end{array}$ & $\begin{array}{l}\text { Jaring apung } \\
\text { Floating nets }\end{array}$ \\
\hline \multicolumn{4}{|l|}{ Chloeophyceae } \\
\hline Chollera vulgaris & 38 & 32 & 26 \\
\hline Closteriopsis longgisima & & & 10 \\
\hline Scenedesmus & & & 2 \\
\hline Enteromorpha & 40 & 38 & 65 \\
\hline Pediastrum & 2 & 9 & \\
\hline \multicolumn{4}{|l|}{ Cyanophyceae } \\
\hline Oscillatoria & & & 4 \\
\hline \multicolumn{4}{|l|}{ Zooplankton } \\
\hline \multicolumn{4}{|l|}{ Rotifera } \\
\hline Brachionus sp. & 7 & 11 & 16 \\
\hline $\begin{array}{l}\text { Jumlah: Individu/L } \\
\text { Total: Individual/L }\end{array}$ & 87 & 90 & 123 \\
\hline $\begin{array}{ll}\text { Indeks nilai } & \text { (Value Index): } \\
0-2.000 & \text { : oligotrofik } \\
2.000-5.000 & : \text { mesotrofik } \\
5.000 \tilde{A} & : \text { eutrofik (s }\end{array}$ & $\begin{array}{l}\text { urang subur)/olig } \\
\text { cukup subur)/mes } \\
\text { gat subur)/eutrop }\end{array}$ & $\begin{array}{l}\text { otrophic (less rich) } \\
\text { otrophic (quite rich) } \\
\text { hic (very rich) }\end{array}$ & \\
\hline
\end{tabular}

\section{UCAPAN TERIMA KASIH}

Dalam kesempatan ini penulis mengucapkan terima kasih kepada para teknisi yang telah membantu terlaksananya penelitian ini hingga selesai. Penelitian ini dibiayai oleh DIPA 2017 Balai Riset Perikanan Budidaya Air Tawar dan Penyuluhan Perikanan.

\section{DAFTAR ACUAN}

Effendie, M.I. (1975). Metode biologi perikanan. Bagian Ichtyologi. Fakultas Perikanan, Insitut Pertanian Bogor. Bogor, $81 \mathrm{hlm}$.

Effendi, H. (2003). Telaah kualitas air, bagi pengelolaan sumber daya dan lingkungan perairan. Kanisius, $257 \mathrm{hlm}$.

Emaliana, E., Usman, S., \& Lesmana, I. (2016). Pengaruh perbedaan suhu terhadap pertumbuhan benih ikan mas koi (Cyprinus carpio). Aquacoastmarine, 13(3), 16-25.

Froese, R. (2006). Cube law, condition factor and weight-length relationships: history, meta-analysis and recommendations. Journal of Applied Ichthyology, 22, 241-253.
Handoyo, B., Setiowibowo, C., \& Yustiran, Y. (2010). Cara mudah budi daya dan peluang bisnis ikan baung dan jelawat. Bogor: IPB Press, $161 \mathrm{hlm}$.

Jenning, S., Kaiser, M.J., \& Reynolds, J.D. (2001). Marine fishery ecology. Blackwell Sciences, Oxford.

Kusakabe, K., Hata, M., Shoji, J., Hori, M., \& Tomiyama, T. (2017). Effects of water temperature on feeding and growth of juvenile marbled flounder (Pseudopleuronectes yokohamae) under laboratory conditions: evaluation by group-and individual-based methods. Fisheries science, 83(2), 215-219.

Kristanto, A.H., Subagja, J., Ath-thar, M.H.F., Arifin, 0.Z, Prakoso, V.A., \& Cahyanti, W. (2016). Pengaruh suhu inkubasi induk dan pemberian naungan pada larva Terhadap produksi benih ikan baung. Prosiding Forum Inovasi Teknologi Akuakultur, hlm. 163-167.

Mudjiman, A. (2004). Makanan ikan. Jakarta: PT Penebar Swadaya, $191 \mathrm{hlm}$.

Murjani, A. (2011). Culture some variety of three spot gourami (Trichogaster trichopterus) with the feeding commercial fed. Jurnal Fish Scientiae, 1(2), 214-233 (In Indonesian). 
Primaningtyas, A.W., Hastuti, S., \& Subandiyono. (2015). Performa produksi ikan lele (Clarias gariepinus) yang dipelihara dalam sistem budidaya berbeda. Journal of Aquaculture Management and Technology, 4(4), 51-60.

Sachlan, M. (1982). Planktonologi. Fakultas Peternakan dan Perikanan Universitas Diponegoro. Semarang, $177 \mathrm{hlm}$.

Salari, R., Saad, C.R., Kamarudin, M.S., \& Zokaeifar, H. (2012). Effects of different stocking densities on tiger grouper juvenile (Epinephelus fuscoguttatus) growth and a comparative study of the flow-through and recirculating aquaculture systems. African Journal of Agricultural Research, 7(26), 3765-3771.

Soedarti, T., Aristiana, J., \& Soegianto, A. (2006). Diversitas fitoplankton pada ekosistem perairan Waduk Sutami, Malang. Jurnal Universitas AirlanggaSurabaya, hlm. 97-103.
Subagja, J., Cahyanti, W., Nafiqoh, N., \& Arifin, O.Z. (2015). Keragaan bioreproduksi dan pertumbuhan tiga populasi ikan baung (Hemibagrus nemurus Val. 1840). Jurnal Riset Akuakultur, 10(1), 25-32.

Walpole, R.E. (1995). Pengantar statistik. Edisi 3. Alih Bahasa: Bambang Sumantri. Jakarta: Gramedia Pustaka Utama.

Weatherley, A.H. \& Gill, H.S. (1987). The biology of fish growth. Toronto, Canada: Academic press, $443 \mathrm{pp}$.

Yuningsih, H.D., Anggoro, S., \& Soedarsono, P. (2014). Hubungan bahan organik dengan produktivitas perairan pada kawasan tutupan eceng gondok, perairan terbuka dan kerambajaring apung di Rawa Pening Kabupaten Semarang, Jawa Tengah. Management of Aquatic Resources Journal, 3(1), 37-43. 